Meta

Journal des traducteurs

Translators' Journal

\title{
In Search of Terms: An Empirical Approach to Lexicography
}

\section{Amelie Josselin-Leray et Roda P. Roberts}

Volume 50, numéro 4, décembre 2005

Pour une traductologie proactive - Actes

For a Proactive Translatology — Proceedings

Por una traductología proactiva - Actas

URI : https://id.erudit.org/iderudit/019920ar

DOI : https://doi.org/10.7202/019920ar

Aller au sommaire du numéro

Éditeur(s)

Les Presses de l'Université de Montréal

ISSN

0026-0452 (imprimé)

1492-1421 (numérique)

Découvrir la revue

Citer cet article

Josselin-Leray, A. \& Roberts, R. P. (2005). In Search of Terms: An Empirical Approach to Lexicography. Meta, 50(4). https://doi.org/10.7202/019920ar

\section{Résumé de l'article}

Dans le cadre d'un travail portant plus largement sur la place et le rôle des termes (c'est-à-dire des mots appartenant aux langues de spécialité) dans les dictionnaires généraux, une étude empirique a été menée auprès de diverses catégories d'utilisateurs de ce type de dictionnaires, parmi lesquelles des scientifiques, des langagiers et des utilisateurs du grand public, pour analyser leur pratique actuelle en matière d'utilisation des ressources documentaires et dictionnairiques pour la recherche des termes. Nous nous proposons ici d'exposer les résultats de cette enquête, et de voir quel impact ceux-ci pourraient avoir sur la pratique lexicographique actuelle.
Ce document est protégé par la loi sur le droit d'auteur. L'utilisation des services d’Érudit (y compris la reproduction) est assujettie à sa politique d'utilisation que vous pouvez consulter en ligne.

https://apropos.erudit.org/fr/usagers/politique-dutilisation/ 


\title{
In Search of Terms: An Empirical Approach to Lexicography
}

\author{
AMELIE JOSSELIN-LERAY \\ Université Lumière Lyon II, Lyon, France \\ josselinleray@neuf.fr \\ RODA P. ROBERTS \\ University of Ottawa, Ottawa, Canada \\ roda.roberts@uottawa.ca
}

\begin{abstract}
RÉSUMÉ
Dans le cadre d'un travail portant plus largement sur la place et le rôle des termes (c'est-à-dire des mots appartenant aux langues de spécialité) dans les dictionnaires généraux, une étude empirique a été menée auprès de diverses catégories d'utilisateurs de ce type de dictionnaires, parmi lesquelles des scientifiques, des langagiers et des utilisateurs du grand public, pour analyser leur pratique actuelle en matière d'utilisation des ressources documentaires et dictionnairiques pour la recherche des termes. Nous nous proposons ici d'exposer les résultats de cette enquête, et de voir quel impact ceux-ci pourraient avoir sur la pratique lexicographique actuelle.
\end{abstract}

\begin{abstract}
In the framework of a more general research project on the place and role of terms (i.e. lexical items belonging to languages for special purposes) in general dictionaries, an empirical study was undertaken with different categories of users of such dictionaries - language experts, scientists and the general public. The purpose of the study was to investigate the use they make of documentary and dictionary resources to find the terms they need. This paper will present some of the results of the survey conducted and examine the impact that these results could have on the practice of lexicography.
\end{abstract}

\section{MOTS-CLÉS/KEYWORDS}

terms, general dictionaries, lexicography, survey, dictionary users

\section{Introduction}

The overall goal of Amélie Josselin's PhD thesis Place et rôle de la terminologie dans les

dictionnaires généraux unilingues et bilingues. Etude du domaine de la volcanologie is to attempt to improve the treatment of terminology in general dictionaries by ensuring that user needs are met. She uses empirical methods to attain that goal, conducting surveys to identify what dictionary users want and need as far as terms are concerned.

This paper will focus specifically on the surveys conducted. In the first section, a rationale for the use of surveys will be presented. In the second section, the surveys used will be described.

Finally, in the third section, some results from the surveys will be analyzed and the impact that these results could have on the practice of lexicography will be explored.

\section{Rationale for the Use of Surveys}

Although dictionaries, like all reference works, have as their primary, if not only, purpose to respond to user needs, dictionary producers have traditionally taken users for granted, making little effort to find out what they want. In fact, while dictionaries have been produced for centuries, it took till 1960 that the issue of dictionary use and users was first brought up at the Conference on Lexicography at 
Indiana University (Householder 1962: 279). However, since that first mention, and especially since Herbert Ernst Wiegand introduced a "sociology of dictionary use" in the mid-1970's, several studies have focused on the needs of dictionary users (Hartmann 1989: 102).

These user studies vary in their focus. Some analyze the types of information users reference in unilingual or bilingual dictionaries (e.g. Barnhart 1962, Tomaszczyk 1979, Béjoint 1981). Others investigate users' degree of satisfaction with their dictionaries (e.g. Galisson 1983, Mackintosh 1995). Still others explore the question of the type of dictionaries that users turn to when faced with certain tasks (e.g. Baxter 1980, Atkins and Knowles 1990). Finally, researchers such as Ard (1982) and Starren and Thelen (1990) have evaluated user performance when performing certain tasks using certain types of dictionaries. Several of these studies have touched on more than one aspect of dictionary use.

While all these studies have used empirical approaches, the specific method employed to explore the questions indicated above varies from one study to another. The three main methods used are questionnaires (i.e. surveys), direct observation and assessment tests, all of which possess certain advantages and disadvantages.

Direct observation, which allows researchers to watch users in action, to take notes on what subjects are doing in the process of performing a certain task such as writing an essay or translating, and even to record the users in action, is a method that can yield in-depth information. But direct observation may affect user performance and behavior, for example by making users highly nervous. Moreover, it is a very time-intensive method, which means that the number of subjects observed is very limited. For this last reason, in particular, direct observation has been used by only a handful of researchers, such as Ard 1982 and Mackintosh 1995.

Testing, which is the primary means to assess user performance, provides concrete information about what participants are doing. It is a more effective means than direct observation of gathering data from a large sample group, since many subjects can be tested at once. Assessment tests have been fruitfully used by researchers such as Bensoussan et al.(1984), Nesi (1994) and Martin-Rutledge (1998). However, test situations may influence the behavior of participants, making the test results sometimes suspect.

The empirical method used by the vast majority of researchers studying dictionary users and use is that of the questionnaire or survey. This is because questionnaires are a practical and costefficient way of gathering information from large sample groups. Another advantage of the questionnaires is that they can be filled out whenever the subjects have the time, which of course could also have the disadvantage of lowering the number of respondents. The main disadvantage of questionnaires is that respondents are suspected of providing information that they believe portrays them in the best light, rather than information that is authentic. However, this disadvantage is not great enough to outweigh the advantages of the large number of subjects that can be questioned at limited cost, which explains the popularity of this method and the reason why it was adopted by Josselin as well.

\section{Description of the Questionnaires Used}

Most of the surveys carried out on dictionnaries so far have dealt primarily with general language, although in some cases terms have been included among many other elements brought up (e.g. in the survey designed for the Bilingual Canadian Dictionary Project, see Roberts 1994). One notable exception is Candel's survey on the use of dictionaries for scientific and technical French words (Candel 2001). Candel's survey, however, is somewhat dated, since it was undertaken twenty years ago, in 1985. Moreover, its scope was limited by the fact that it covered only the French language and unilingual dictionaries in that language and by the fact that it was intended only for scientific and technical experts.

While the focus of our survey, like Candel's, is only terms, it covers both unilingual and bilingual general dictionaries, and two languages, French and English. Four different questionnaires were prepared depending on the language and the type of dictionary: UniFR, written in French, deals with unilingual French dictionaries; UniEN, written in English, with unilingual English dictionaries; BiFR, written in French, and BiEN, written in English, deal with bilingual English- 
French dictionaries. Each questionnaire contains 19 questions, which are closed questions with dichotomous or multiple choice answers. The questions are designed to solicit facts, opinions or intentions, and allow for the possibility of adding personal comments.

The questionnaires have three main functions, with each function covered by a certain number of questions:

1. To determine whether terms are included in general dictionaries because users really need or want them.

Figure 1: Example of a Question Pertaining to Function 1 of the Survey

B.1.6) Do you look up scientific and technical words ${ }^{1}$ (e.g. shield volcano, hammer, endless screw, compass) in a general English dictionary?

- Yes

- No

2. To establish what specific use users make of general dictionaries as far as terms are concerned.

Figure 2: Example of a Question Pertaining to Function 2 of the Survey

B.1.9) When you look up scientific or technical words in an English general dictionary, are they:

- Always in the same field(s) (e.g. Biology, Law, Architecture)? If possible, please specify which one(s).

- In a wide range of fields?

3. To evaluate whether the treatment of terms in general dictionaries corresponds to user needs and expectations.

Figure 3: Example of a Question Pertaining to Function 3 of the Survey

B.1.12) What do you think of the following characteristics in the general English dictionary that you most often use ?

Please specify the NAME OF THE DICTIONARY:

\begin{tabular}{|c|c|c|c|c|}
\hline & & 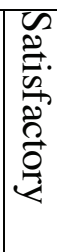 & 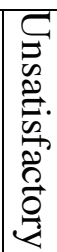 & $\begin{array}{l}\text { Z } \\
\text { o } \\
0 \\
\text { o. } \\
\text { :. }\end{array}$ \\
\hline \multicolumn{5}{|c|}{ Global number of scientific and technical words } \\
\hline \multicolumn{5}{|c|}{ Number of recent scientific and technical words (e.g. chatroom, smiley) } \\
\hline \multicolumn{5}{|c|}{$\begin{array}{l}\text { Number of multi-element scientific and technical words (e.g. monoamine } \\
\text { oxidase inhibitor) }\end{array}$} \\
\hline \multirow{2}{*}{$\begin{array}{l}\text { Definitions of } \\
\text { the scientific } \\
\text { and technical } \\
\text { words }\end{array}$} & Clarity & & & \\
\hline & Scientific accuracy & & & \\
\hline \multicolumn{2}{|c|}{$\begin{array}{l}\text { Balance between various fields (e.g. Mathematics is as well treated as } \\
\text { Chemistry) }\end{array}$} & & & \\
\hline
\end{tabular}




\begin{tabular}{|c|c|}
\hline \multirow[t]{2}{*}{$\begin{array}{l}\text { Field } \\
\text { Indication }\end{array}$} & using a label such as Econ., Med., Biochem. \\
\hline & using other means \\
\hline \multirow{2}{*}{$\begin{array}{l}\text { Information } \\
\text { about the way } \\
\text { to use the } \\
\text { word in a } \\
\text { sentence }\end{array}$} & using an example \\
\hline & using another means (e.g. « Always followed by $a t »)$ \\
\hline
\end{tabular}

The questionnaires were addressed to three different types of users: language specialists (e.g. translators, editors, language teachers); sci-tech experts (e.g. engineers, technicians, researchers), and the general public. The category of general public consisted basically of relatively well-educated persons who were neither language nor sci-tech specialists. Each type consisted of two subgroups: those already trained and those still in training.

The questionnaires were distributed in two different ways. They were sent by e-mail to specific individuals. They were also made available on the website of the Bilingual Canadian Dictionary Project. A number of individuals falling into one of the three user types mentioned above were identified on the basis of the researchers' knowledge of their background and, for some of those selected for their expertise in the language or sci-tech fields, on the basis of membership lists of pertinent professional associations. All of the individuals contacted were asked to inform their friends/colleagues about the questionnaires and direct them, if necessary, to the website.

The number of questionnaires received by type of questionnaire is presented below (Table 1).

Table 1: Number of Questionnaires Received

\begin{tabular}{|l|l|l|l|}
\hline & $\begin{array}{l}\text { Unilingual } \\
\text { dictionaries }\end{array}$ & $\begin{array}{l}\text { Bilingual } \\
\text { dictionaries }\end{array}$ & Total \\
\hline English & 119 & 95 & 214 \\
\hline French & 227 & 206 & 433 \\
\hline Total & 346 & 301 & $\mathbf{6 4 7}$ \\
\hline
\end{tabular}

The percentage of users belonging to each of the user types identified above is indicated below by type of questionnaire (Figure 4). 
Figure 4: Distribution of Respondents by Major User Types

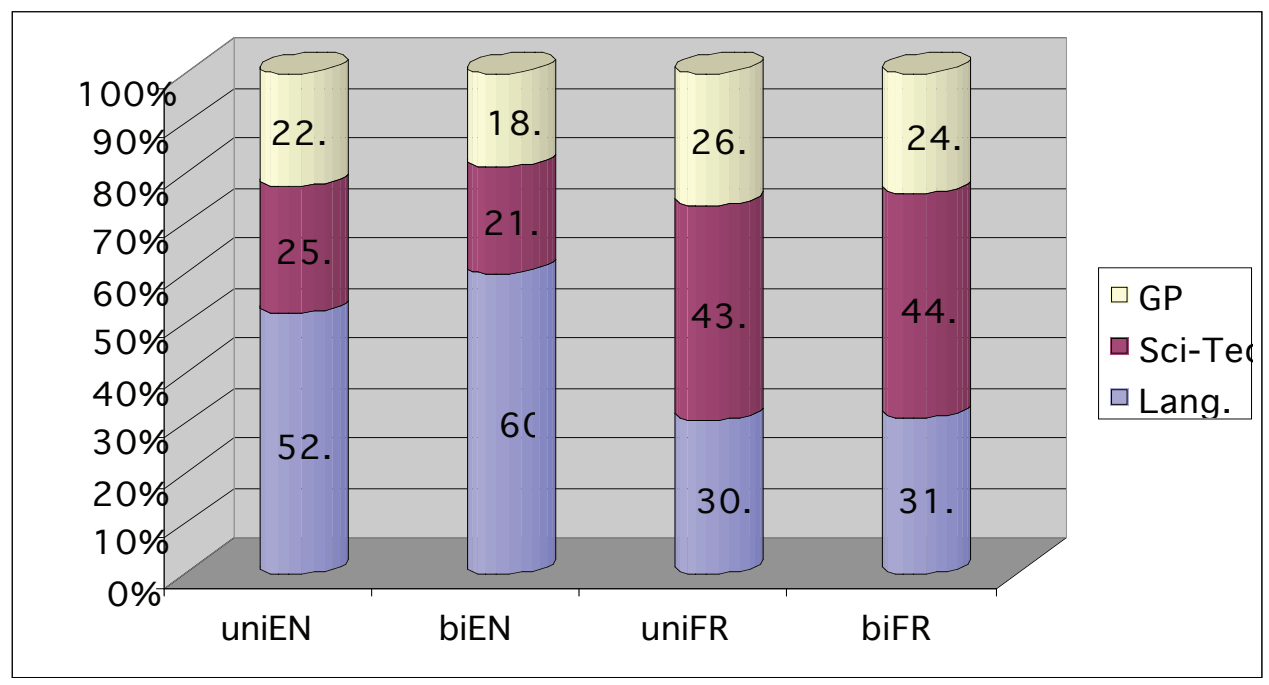

\section{Some Results}

It is obviously impossible, in the framework of this article, to present the results from all 19 questions asked in the survey. Here, we will focus on questions dealing only with one objective of the survey, and with only one sub-objective of that one objective. The latter are presented below:

- Objective 1:

To determine whether terms are included in general dictionaries because users really need or want them.

- Sub-objective:

To determine to what degree users consider the inclusion of terms necessary in general dictionaries, and to what extent opinions vary according to user types.

Four questions correspond to this sub-objective. They involve criteria for the purchase of a general dictionary (B.16), an opinion on whether a dictionary without specialized terms (as opposed to common terms) can be considered a good dictionary (B.17), justification of the answer to the previous question (B.17), if the response was no or maybe (B.18), and an opinion as to whether the subject would buy a general dictionary that did not contain specialized terms (B.19). Each of these questions, which were asked both in the unilingual dictionary questionnaires and the bilingual dictionary questionnaires, will be examined in turn.

\subsection{Criteria for the Purchase of a Unilingual General Dictionary}

The question was worded as follows in the English unilingual dictionary questionnaire. The same question, with changes in examples, is found in the UniFR, BiEN and BiFR questionnaires.

Figure 5 : Question B.16

B.1.16) What are your criteria for buying a general English dictionary?

- Famous name (e.g. Webster's, Collins...)

- Price:

If price, what is your price range?

$$
\begin{aligned}
& \text { Less than } \$ 20 \mathrm{CD} / / \text { \$15US // } € 15 / / £ 10 \\
& \$ 20-40 \mathrm{CD} / / \text { \$15-30 US // €15-30//£10-20 } \\
& \$ 40-60 \mathrm{CD} / / \$ 30-45 \text { US // } € 30-45 / / £ 20-30 \\
& \$ 60-100 \mathrm{CD} / / \$ 45-75 \text { US // €45-75//£30-50 }
\end{aligned}
$$


- Dictionary size

- Presence of illustrations

- Presence of numerous scientific and technical words

- Presence of new words

- Other (please specify)

The results are presented in the form of a table below (Table 2), with the criteria organized in descending order of importance.

Table 2 : Summary of the Results for Question B.16

\begin{tabular}{|l|l|l|l|l|}
\hline & UniEN & BiEN & UniFR & BiFR \\
\hline $\mathbf{1}$ & Name (56.9\%) & Name (65.6\%) & Name $(76.1 \%)$ & Name (76.9\%) \\
\hline $\mathbf{2}$ & $\begin{array}{l}\text { New words } \\
(45.7 \%)\end{array}$ & $\begin{array}{l}\text { Number of translations } \\
(46.8 \%)\end{array}$ & $\begin{array}{l}\text { New words } \\
(39.6 \%)\end{array}$ & $\begin{array}{l}\text { Number of translations } \\
(63.8 \%)\end{array}$ \\
\hline $\mathbf{3}$ & Size $(40.5 \%)$ & New words $(46.2 \%)$ & Terms $\mathbf{( 3 7 . 8 \% )}$ & Size $(43.7 \%)$ \\
\hline $\mathbf{4}$ & Price $(35.3 \%)$ & Size $(53.8 \%)$ & Size $(35.1 \%)$ & Terms (40.2\%) \\
\hline $\mathbf{5}$ & Terms (24.1\%) & Price (34.4\%) & $\begin{array}{l}\text { Illustrations } \\
(33.8 \%)\end{array}$ & New words (36.2\%) \\
\hline $\mathbf{6}$ & $\begin{array}{l}\text { Illustrations } \\
(11.2 \%)\end{array}$ & Terms $(\mathbf{1 9 . 4 \% )}$ & Price $(29.3 \%)$ & Price (28.1\%) \\
\hline $\mathbf{7}$ & & Illustrations (5.4\%) & & Illustrations $(9.0 \%)$ \\
\hline
\end{tabular}

Obviously, the purchase criterion that is of most interest to us is the one related to the presence of terms in the dictionary. Interestingly, it does not seem a very important criterion to users, since it never figures among the top two. However, it is obviously a more significant factor in the French questionnaires than in the English questionnaires, and in the unilingual questionnaires than in the bilingual questionnaires.

If we now look at this purchase criterion from the point of view of user types, we also note differences between the English and French questionnaires.

Figure 6: Distribution of Respondents who Consider the Presence of Terms Important as a Purchase Criterion

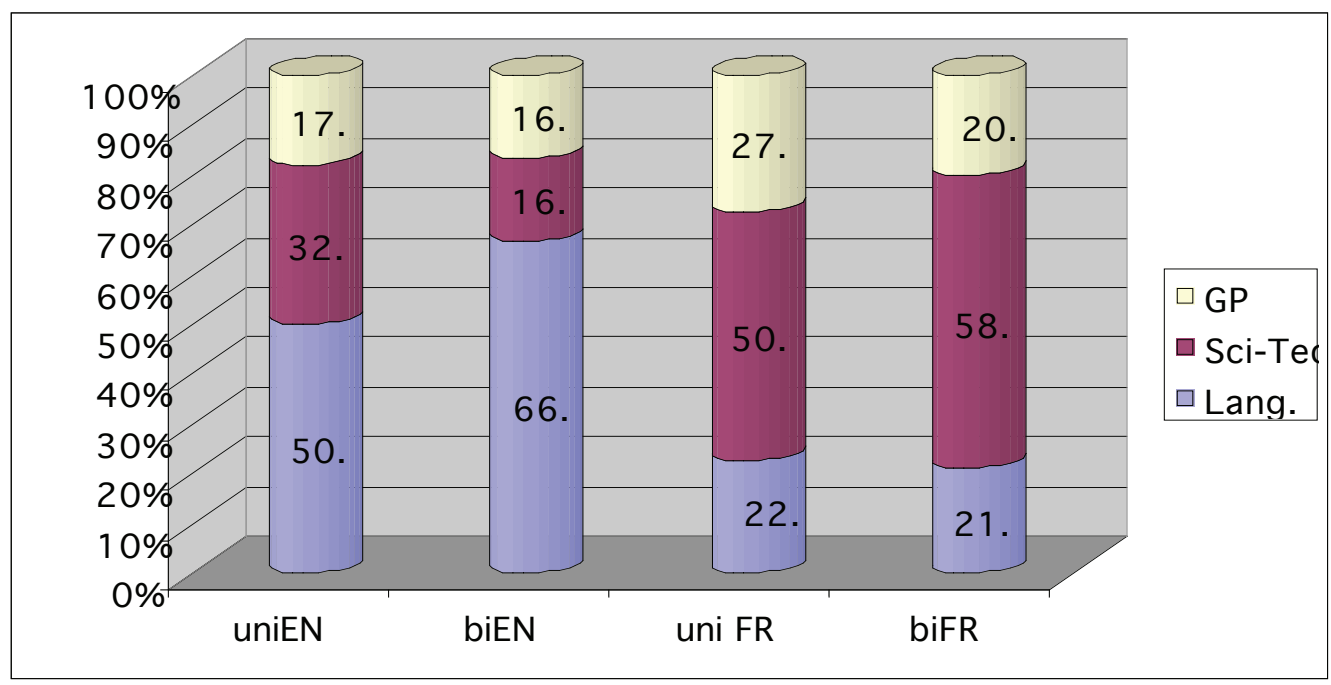


As the above diagram shows (Figure 6), the presence of terms in a dictionary was more important to language specialists responding to the English questionnaires and to sci-tech personnel responding to the French questionnaires. However, use of the chi-square test reveals that these results cannot conclusively be applied to a wider group of respondents.

3.2. A Dictionary Without Terms: a Good Dictionary ?

The question was worded as follows in the English unilingual dictionary questionnaire. The same question, with changes in examples, is found in the UniFR, BiEN and BiFR questionnaires.

Figure 7: Question B. 17

B.1.17) In your opinion, could a general monolingual dictionary without any specialized scientific or technical words (e.g. shield volcano, rachianalgesia, endless screw) be a good dictionary?

- $\quad$ Yes

- $\quad$ No

- $\quad$ Maybe

The results are presented in the diagram below (Figure 8).

Figure 8: Distribution of Answers to Question B.17

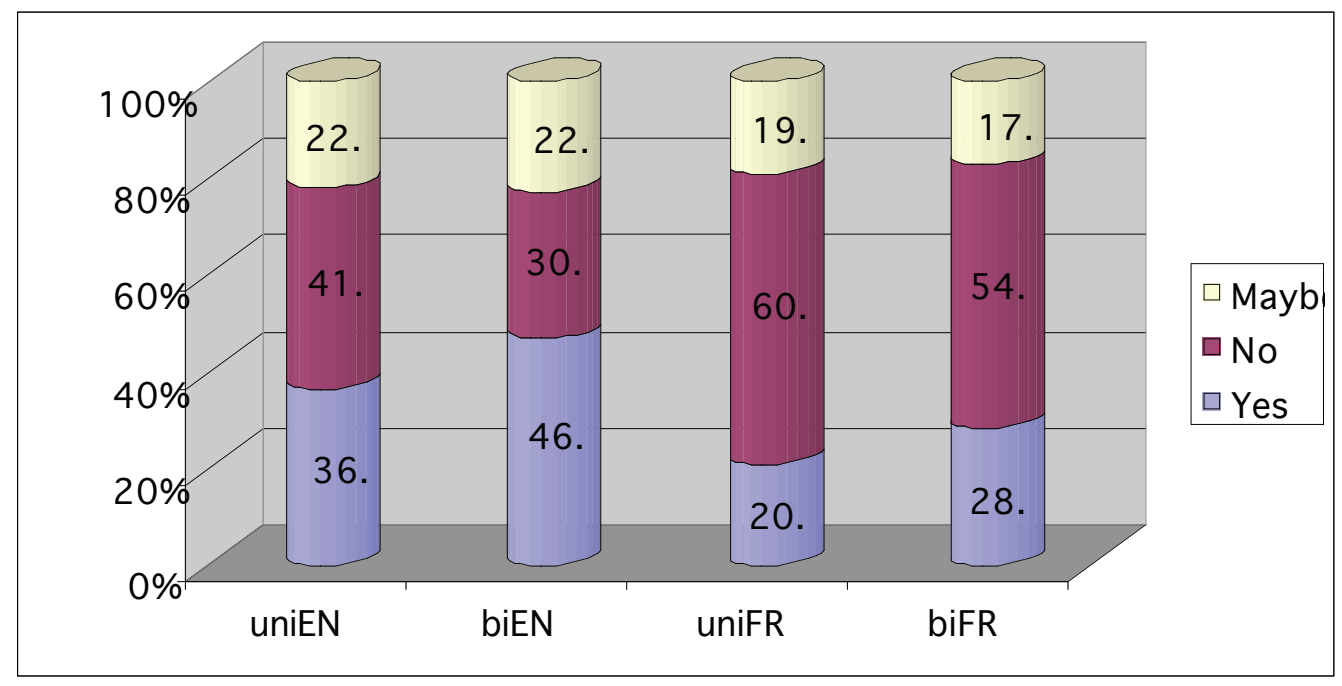

While respondents to the French questionnaires gave a categorical no to the question, those answering the English questionnaire were less negative. On the French sides, the sci-tech experts were the most vocal in their answer.

\subsection{Justification of the Response to Question B.17, if not Affirmative}

This question was worded as follows (N.B. in the bilingual dictionary questionnaires, "bilingual dictionary" was substituted for "monolingual dictionary"):

\section{Figure 9: Question B.18}

B.1.18) If you answered NO or MAYBE to the previous question, please justify your answer. Otherwise, move on to question B.1.19.

- The monolingual dictionary would not fully represent the world of today 
- The monolingual dictionary would not constitute a source of knowledge

- You might some day want to look up a specialized scientific or technical word in a monolingual dictionary

- Other (please specify)

The results are presented, in descending order of importance, in the following table (Table 3), in which the first justification above is abbreviated as "Modernity", the second as "Knowledge", and the third as "Exhaustiveness".

Table 3 : Summary of the Results for Question B.18

\begin{tabular}{|l|l|l|l|l|}
\hline & UniEN & BiEN & UniFR & BiFR \\
\hline 1 & $\begin{array}{l}\text { Exhaustiveness } \\
(65.3 \%)\end{array}$ & $\begin{array}{l}\text { Exhaustiveness } \\
(67.4 \%)\end{array}$ & $\begin{array}{l}\text { Exhaustiveness } \\
(76.7 \%)\end{array}$ & $\begin{array}{l}\text { Exhaustiveness } \\
(80.5 \%)\end{array}$ \\
\hline 2 & Modernity $(54.2 \%)$ & Modernity $(52.2 \%)$ & Knowledge $(51.8 \%)$ & Knowledge (45.1\%) \\
\hline 3 & Knowledge $(36.1 \%)$ & Knowledge $(41.3 \%)$ & Modernity $(28.7 \%)$ & Modernity $(28.6 \%)$ \\
\hline
\end{tabular}

Exhaustiveness is the reason given by the largest percentage of respondents to all questionnaires. But as in question B.16, language experts account largely for this result in English, and the sci-tech personnel in French.

Modernity is more important to those answering the English questionnaires. Once again, this factor is more important for language specialists than sci-tech specialists in English. However, these two groups seem to share more or less the same opinion in French.

Finally, knowledge is more important to those answering the French questionnaires, particularly for sci-tech experts.

3.4 Would Users Purchase a General Dictionary Without Specialized Terms ? The question was very simply worded as follows (N.B. in the bilingual dictionary questionnaires, "bilingual dictionary" was substituted for "monolingual dictionary"):

Figure 10 : Question B.19

B.1.19) Would you buy a general monolingual dictionary without any specialized scientific and technical words?

- Yes

- No

- Maybe

The following diagram (Figure 11) presents the results. 
Figure 11: Distribution of Answers to Question B.19

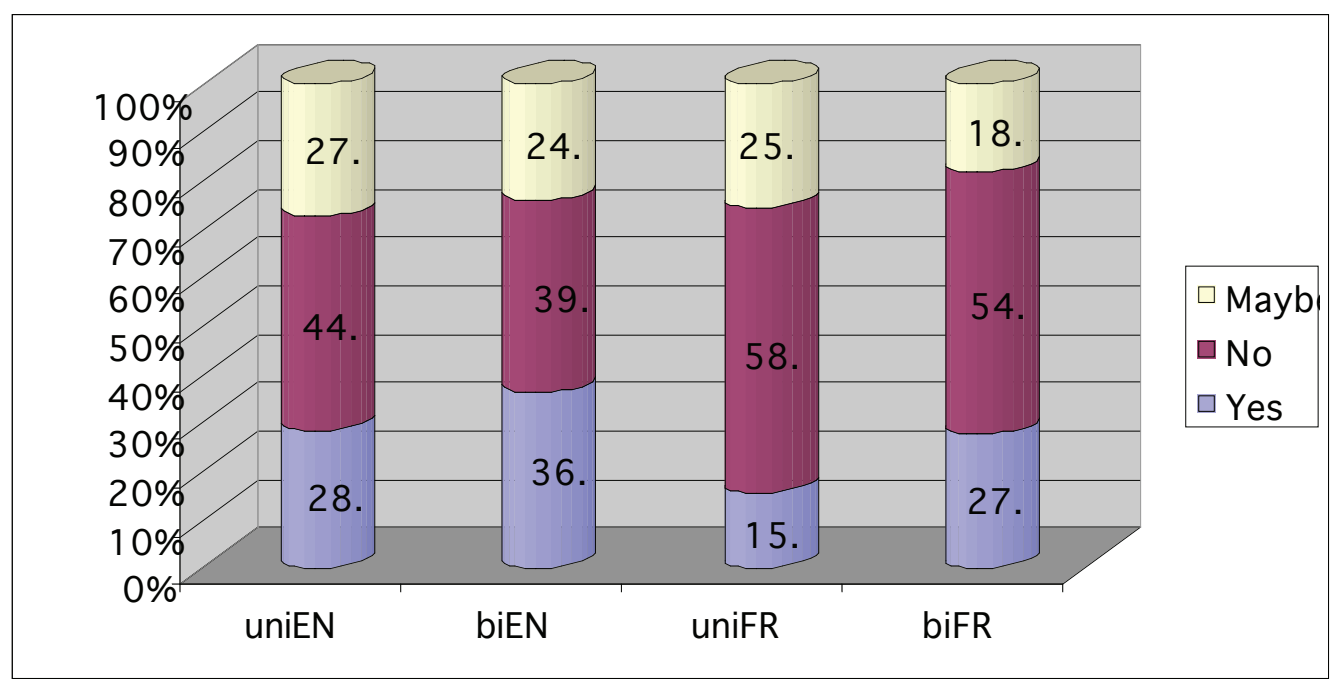

In all questionnaires, the majority answer to the question was no. The negative response was more evident in the French questionnaires, which is in keeping with the answers to question B.18 in French, where exhaustiveness was a more important factor. However, there is no great difference in the responses provided by the three main user groups.

\subsection{Conclusions Regarding Sub-Objective 1}

As indicated at the start of section 3, we have examined in this article results of questions pertaining to sub-objective 1, which involves determining the degree to which users consider the inclusion of terms in general dictionaries a necessity, and showing any differences between three main user groups in this regard.

The results can be summarized as follows: (1) All user groups feel that terms should be included in general dictionaries. (2) The reason for this response from all three user groups seems to be the exhaustiveness of coverage that they expect from such dictionaries. (3) However, the inclusion of terms seems to be most important for sci-tech personnel, especially those who responded to the French questionnaires; this is not surprising, given that such experts use specialized vocabulary constantly.

\section{Conclusion}

Although the questions treated here are related to a very narrow sub-objective, the consequences of the responses are important. First, the user survey allows lexicographers to justify the inclusion of a large number of terms in general dictionaries. Second, it provides lexicographers, metalexicographers and dictionary users a criterion for evaluating general dictionaries.

If we had considered a wider objective here (e.g. objective 2, which deals with the specific use users make of general dictionaries as far as terms are concerned), it would become clear that the responses to the questionnaires affect not only the content of the dictionary, in terms of the macrostructure, but also the treatment of terms in the microstructure.

Or, at least, the responses should have that effect. For dictionaries are supposed to be written for users and it is imperative that lexicographers provide them with what they need or want. 


\section{NOTES}

1. In the questionnaires, "scientific and technical words" was used in preference to the word "term" to avoid any misunderstanding on the part of respondents.

\section{REFERENCES}

ARD, J. (1982): “The Use of Bilingual Dictionaries by ESL Students while Writing”, ITL 58, p. 1-28.

ATKINS, B. T. and F. KNOWLES (1990): "Interim Report on the EURALEX/AILA Research Project into Dictionary

Use", in MAgay, T. and J. ZIGANY (eds.): Budalex 88 Proceedings. Papers from the 3rd International EURALEX

Congress, Budapest, 4-9 September 1988, Budapest, Akadémia Kado, p. 381-392.

BARnhaRT, C. L. (1962): "Problems in Editing Commercial Monolingual Dictionaries", in Householder, F. and S. SAPORTA (eds.): Problems in Lexicography, Bloomington, Indiana University, p. 161-182.

BAXTER, J. (1980): “The Dictionary and Vocabulary Behavior: A Single Word or a Handful?", TESOL Quaterly XIV, pp. 325-336.

BÉJOINT, H. (1981): “The Foreign Student's Use of Monolingual English Dictionaries: A Study of Language Needs and Reference Skills", Applied Linguistics 2-3, p. 207-222.

Bensoussan, M. et al.(1984): "The Effect of Dictionary Usage on EFL Test Performance Compared with Student and Teacher Attitudes and Expectations", Reading in a Foreign Language 2 , p. 262-276.

CANDEL, D. (2001) : « De l'usage des dictionnaires de spécialité (Une enquête 1985-2000) », Cahiers de Lexicologie 78-1, p. 91-98.

GALISSON, R. (1983): « Image et usage du dictionnaire chez des étudiants (en langue) de niveau avancé », Études de linguistique appliquée 49, p. 5-88.

Hartmann, R. (1989): "Sociology of the Dictionary User: Hypotheses and Empirical Studies", in Hausmann, F.

J. et al. (eds.): An International Encylopedia of Lexicography, Berlin , Walter de Gruyter, p. 102-111.

HouseHOlder, F. (1962): "Summary Report", in HousEHOlder, F. and S. SAPORTA (eds.): Problems in

Lexicography, Bloomington, Indiana University, p. 279-282.

MACKInTOSH, K. (1995): “An Empirical Study of Dictionary Use in Version”, MA Thesis, University of Ottawa. MARTin-RutLedge, V. (1998): "Use of Examples in the Bilingual Dictionary: An Empirical Study”, MA Thesis, University of Ottawa.

NESI, H. (1994): "Effect of Language Background and Culture on Productive Dictionary Use", in MARTIN, W. et al. (eds.): EURALEX 94 Proceedings. Papers submitted to the 6th EURALEX International Congress on Lexicography in Amsterdam, The Netherlands, The Netherlands, p. 577-585.

RoberTs, R. P. (1994): "Bilingual Dictionaries Prepared in Terms of Translators' Needs", in LoYER, N. et al. (ed.): Translation in the Global Village. Proceedings of the 3rd Conference of the Canadian Translators and Interpreters Council held in Banff, Alberta, May 4 to 8, Banff, CTIC, p. 51-65.

Starren, P. and M. Thelen (1990): "General Dictionaries and Students of Translation: A Report on the Use of Dictionaries in the Translation Process", in MAgay, T. and J. ZigAny (eds.): Budalex 88 Proceedings. Papers

from the 3rd International EURALEX Congress, Budapest, 4-9 September 1988, Budapest, Akadémia Kado, p. 447458.

TOMASZCZYK, J. (1979): “Dictionaries: Users and Uses”, Glottodidactica XII, p. 103-119. 